\title{
A Corporate Governance Reform as a natural experiment for incentive contracts
}

\author{
Christian Bayer* Carsten Burhop $^{\dagger \ddagger}$
}

FIRST VERSION: 05.06.03

THIS VERSION: 17.09 .03

ABSTRACT

In this paper, we exploit a major reform of the legal rules of corporate governance to test for the incentive character of managerial contracts.

As such reforms are rare, this test is only possible with historical data. Therefore, we employ a dataset from 19th century German banking using dynamic panel estimators. Our main findings are-firstly-that the compensation of executive officers was strongly dependent on firm performance. Secondly, the 1884 reform of corporate governance-which increased monitoring incentives and abilities of shareholders-strongly reduced the pay-performance sensitivity. Hence, this finding strongly supports the hypothesis of incentive related pay.

JEL-Classification: G30, J33, N23

KEYWORDS: pay-performance sensitivity, natural experiment, legal reform, corporate governance

*Universität Dortmund, Graduiertenkolleg "Allokationstheorie, Wirtschaftspolitik und kollektive Entscheidungen", D-44221 Dortmund, Germany, e-mail: christian.bayer@wiso.unidortmund.de.

${ }^{\dagger}$ University of Muenster, Institute for Economic and Social History, Domplatz 20-22, D48134 Münster, GGermany, e-mail:־burhop@uni-muenster.de [CORRESPONDING AUTHOR]

${ }^{\ddagger}$ We would like to thank Kornelius Kraft, Michael Roos and seminar participants at the University of Dortmund for helpfull comments and suggestions. Christian Bayer would like to thank the Deutsche Forschungsgemeinschaft for financialsupport. This paper was written while Carsten Burhop was a research fellow at the Center for Development Research, Bonn University. Financial support of this institute is gratefully acknowledged. 


\section{Introduction}

One of the first and probably best known applications of principal-agent theory is incentive contracts for managers of publicly owned companies. From theory, managers should be paid according to firm-performance. Yet, the empirical support for this is rather weak. In their seminal article Jensen and Murphy (1990) find that compensation of CEOs increases only by $3.25 \$$ per $1000 \$$ increase in shareholders' wealth. ${ }^{1}$ Given Jensen and Murphy's results the question arises whether the pay-performance sensitivity was always that low or if it has changed over time. And if the sensitivity has changed due to an evolving institutional environment, this gives additional insight on the incentive problems within the firm. We address this issue by analyzing the impact of a large corporate governance reform - the 1884 German joint stock companies act - on the pay-performance relationship within the German banking sector.

This act strictly separated control rights between the supervisory and the executive board of a company and still builds the backbone of the modern German corporate governance code. As the reform aimed at solving problems of corporate control, we can expect moral hazard be of lesser importance in the period after 1884 and the pay-performance link to be much lower. Indeed, we find the pay-performance link to be $50 \%$ smaller in the post-reform period. Conversely, the lower post-reform pay-performance sensitivity serves as evidence for incentive-contracts before the reform, i.e. the reform itself is a natural experiment.

\footnotetext{
${ }^{1}$ Hall and Liebman (1998) find a larger sensitivity for a more recent period. Zhou (2000) analyses Canadian data and Kato (1997) analyses Japanese data. Both report sensitivities that are somewhat larger than what Jensen and Murphy report.

Core et al. (2003) give a review of the recent literature on stock-based Executive Compensation and incentives. Murphy (1999) gives an excellent and very general review of the literature concerning incentive related pay for managers and John and Qian (2003) review the CEO-compensation literature with special focus on the banking industry. Shleifer and Vishny (1997) give a general survey of the literature on corporate governance.

As we will analyse German data, one may wonder if for modern German data the sensitivity of pay to performance is much different to the one for the US. Indeed, the dependency of managerial salaries on profits is also reported to be rather weak for Germany (See e.g. Schwalbach and Graßhoff, 1997, or Kraft and Niederprüm, 1999a and 1999b). For the period analysed, contemporaries criticised the high salaries of managers and the low dependency of manager-salaries on performance (Warschauer 1902).
} 
It is essential to exploit inter-firm or inter-time differences in pay-performance sensitivities. Only if these differences are linked to changes respectively to differences in the institutional or market environment one can obtain a causal interpretation of the pay-performance relationship itself. Himmelberg and Hubbard (2000) or Grossmann (2003) for example argue that general-equilibrium effects already induce some correlation between performance and pay even without any strategic considerations when able managers are scarce. Alternatively, Lazaer (2003) explains the pay-performance sensitivity as a selection device.

One way to empirically asses the importance of incentive reasons for a payperformance sensitivity, i.e. to test the principal-agent model, is the use of the volatility of firm returns. The higher this volatility, the higher the salarybased pay-performance sensitivity should be. Empirical evidence for this is mixed. Aggarwal and Samwick's (1999) results are supportive for the principal agent theory, whereas Garen (1994) and Lambert and Larker (1987) do not find strongly significant differences between high-volatility and low-volatility firms.

One reason for this might be the use of short panels. Managerial contracts are typically multi-period and involve reputation and therefore the dynamic structure of the data is of importance. Simply using fixed- or random-effects OLS estimators might lead to biased results. Using historical data allows us to employ a panel that is long in time dimension. We explicitly take into account the below unit-root autoregressive nature of manager compensation and use the GMM-estimator of Arrellano and Bond (1991).

As the legal system defines the deep parameters that are embedded in the optimal contracts of managers, large changes in the corporate governance code can be used as a test. Large changes in the corporate control code are naturally rare. However, we have a unique data-set that contains accounting data of 9 large German banks covering the period from 1871 to 1910; a period in which the joint-stock company act of 1884 falls. This act is arguably one of the most fundamental reforms the German corporate governance code has undergone so far. Especially, we can expect a legal change in corporate governance to influence the sensitivity of pay with respect to firm-performance. And-as 
said before - we find this sensitivity to be substantially influenced by the legal reform analyzed.

A similar approach has been implemented by Conyon (1997). He analyzes the impact of voluntary changes in corporate governance on the level of CEO compensation for a sample of UK firms. His results suggest a rather weak influence of these corporate governance innovations on compensation. In contrast, Core et al. (1999) find a substantial influence of corporate governance on the compensation-level. Additionally, they show that weaker corporate governance not only increases the level of compensation, but also decreases future firm performance.

The remainder of this paper is now organized as follows. In section 2 , we motivate our identification strategy with a highly stylized model of an incentive contract. Moreover, we describe the major legal-institutional shifts of the 1884 legal-reform of the corporate governance code. Section 3 describes the data set, and section 4 presents the estimation model and the empirical results. Section 5 concludes.

\section{Theoretical and historical preconsiderations}

\subsection{Incentive contracts}

To formalize the basic idea of this paper in a very stylized way, suppose a firm generates profits employing a manager. This manager derives utility from her salary, $w$, which may depend on the profits she reports to the owner of the firm. Additionally, the manager can divert firm resources $s$, which are drawn from firm profits, $\pi$, to private projects (perks) at some private costs $g$. Hence, her utility function is $U=s-g(s ; \pi)+w(\pi, s)$. For simplicity, the only contracts available shall be linear in the reported profits, i.e. $w=\alpha_{0}+a(\pi-s){ }^{2}$

The owner chooses $a$ to maximize her profits $(\pi-s)(1-a)$. The manager

\footnotetext{
${ }^{2}$ Burhop (2003) shows in a historical case study from 19th century German banking that the contracts used were indeed linear .
} 
will chose $s$ according to her first-order condition.

$$
1-g^{\prime}(s ; \pi)-w^{\prime}(\pi-s)=0
$$

If $g$ is quadratic, i.e. $g=\frac{c(s-b \pi)^{2}}{2 \pi}$, one obtains after some calculations for the optimal pay-performance sensitivity:

$$
a^{*}=1-\frac{(1-b) c}{2}
$$

so the optimal fraction of the reported profits, the manager gets is decreasing in the costs of mis-reporting. Therefore a legal reform that increases these cost will lower the fraction of profits the manager appropriates. ${ }^{3}$

Similarly, we can expect the tenure of a manager to affect the pay-performance sensitivity: If a manager that stays longer with the firm has a lower cost of diverting funds, then her profit-share will be larger. Because of that, both of these two effects can be used to test for the incentive character of performance related pay.

\subsection{The 1884 joint-stock company act as a natural experiment}

To see that the 1884 reform can be viewed as a natural experiment indeed, we may shortly describe the historical and legal setting: The legislation of jointstock companies during the 19th century in Germany can be divided into three phases. ${ }^{4}$ The first phase starts with the introduction of the Prussian jointstock companies act in 1838 (for railways) and 1843 (for all other companies). According to these laws, a royal concession was necessary to found such a company and the concessioned companies were supervised by the government.

The second phase, in which the so-called "Gründerboom" of 1871-73 falls, began with a major liberalization of the legal rules concerning joint-stock companies in 1870. Founding a joint-stock company was from then on possible without royal concession and the system of state supervision was disestablished,

\footnotetext{
${ }^{3}$ Analogously, the Holmstrom and Milgrom (1987) optimal linear contract model yields a similar result, when the reform influences the curvature of the disutility of effort.

${ }^{4}$ Hopt (1980) gives a short overview on this.
} 
but a two tier board system was introduced. The minimum nominal face-value of shares issued was reduced to $100 \mathrm{M}$, of which only 40 per cent had to be paid up. This popularized stock-ownership in Germany. Between 1871 and 1873 more than 900 joint-stock companies - over of 100 of them banks - were founded in Germany.

However, in a sense the liberalization went too far: there was no clearcut division of competence between executive and supervisory board (Vorstand and Aufsichtsrat); many of the new companies were unsoundly managed, and therefore the failure rate after the stock-market crash of 1873 was immense. According to contemporaries, the defective law was the main reason for the collapse (see e.g. Glagau 1877).

Following the stock-market-crash of 1873 the laws concerning corporate governance underwent a major reform in 1884 (see for instance Ring 1890). ${ }^{5}$ For the first time, the new law strictly separated the functions of the supervisory and executive board. Moreover, the minimum face value of a share was increased to 1,000 M, the shares had to be paid up in full, ${ }^{6}$ all shareholders got a voting right, and detailed profit- and loss-statements had to be published. This increased the monitoring incentives and abilities of shareholders significantly. Finally, the penalties for misbehavior of supervisory or executive board members were considerably raised.

If managerial compensation was sensitive to performance to induce the right incentives before the reform, we can expect the decline in discretionary power and the higher costs of misbehavior after the reform to lower this sensitivity. Hence, we can use the reform as a natural experiment.

\footnotetext{
${ }^{5}$ The importance of good corporate governance rules was already recognized by contemporary authors, e.g. Philippovich (1909, pp 186) who proposed that monitoring incentives should be strenghted by a high face value of stocks, free speech on the annual meeting of shareholders, clear accounting rules, and extensive control rights even for minority shareholders.

${ }^{6}$ This made holding a diversified portfolio rather infeasible, as the average net-national product per capita was $400 \mathrm{M}$ in 1884 .
} 


\section{Brief description of the data-set}

The main source of data used for this paper is Bosenick (1912) with detailed information for nine large German joint-stock credit banks (Kreditbanken). ${ }^{7}$ In 1910, the last year for which data are reported, these banks had total assets of nearly 7.9 billion Mark and they represented a market share of about 52 per cent of the German joint-stock credit-bank market.

Bosenick reports the profit shares paid to the executive- and supervisoryboard. It is important to note that these two boards were strictly separated only in 1884. Furthermore, one bank - the Schaaffhausensche Bankverein - did not report separate profit shares for executive and supervisory board members until 1905. Therefore, only the total bonus payments to the supervisory and executive board members are used in the regressions. As the size of the board varies, we calculate the average bonus per member of the board. ${ }^{8}$ In addition, we have data on the accounting profits, the share price (relative to the face-value of a share), and the dividend of the nine banks. ${ }^{9}$

Table 1 gives a summary statistics of our deflated data. Table 2 presents the results, we obtain from a Maddala-Wu (1999) Fisher tests for unit-roots. ${ }^{10}$ We can reject the hypothesis of a common unit-root both for profits and the price of stocks on all usual levels of significance. As the banking sector could be expected to grow for the time-period we analyze, we allow for a trend.

For the managers' bonus, our variable of most interest, however, the evidence is mixed. Formally, we cannot reject the unit-root hypothesis. Yet, this

\footnotetext{
${ }^{7}$ Note for the referee: See appendix.

${ }^{8}$ These information is taken from Reitmayer (1999).

${ }^{9}$ All data has been deflated to 1913-prices using the implicit NNP deflator of Hoffmann (1965, pp 825). In addition we also have data on the total assets and subcategories and on total lending. Yet, these items display unit-root behaviour and so are not included in any of our empirical specifications.

The data series start in 1871, but German accounting rules did not prescribe the publication of profit-loss statements until 1884. Therefore, first profit statements of the Schaaffhausensche Bankverein are available for 1884; the Disconto Gesellschaft published first data in 1885. Data series for the Dresdner Bank and for the Nationalbank für Deutschland start in the year of foundation of the respective banks (1873 and 1881).

All members of the board had to be shareholders, too. However, there is no information available on how many shares each board member holds.

${ }^{10}$ The test bases on an ADF-Statistics for each individual bank, allowing for variable laglength, which has been determined using a LM-Test.
} 
Table 1: Descriptive statistics

\begin{tabular}{llllll}
\hline \hline Variable & Obs. & Mean & Std. Dev. & Min & Max \\
\hline Stock-Price (in \%) & 320 & 116.5 & 33.15 & 45.37 & 256.4 \\
Dividends (1000M) & 320 & 4664 & 4329 & 0.00 & 24325 \\
Profit (1000M) & 320 & 5998 & 5785 & -3118 & 31671 \\
Bonus-Payments (1000M) & 320 & 720.0 & 794.6 & 0.00 & 4804
\end{tabular}

Table 2: Significance of a unit-root,

\begin{tabular}{llc}
\multicolumn{2}{c}{ Maddala-Wu (1999) Fisher-Test } \\
\hline \hline Variable & With & No. of individual \\
& Trend & \begin{tabular}{c} 
rejections at 10\% \\
\hline Profit
\end{tabular} \\
Bonus & $37.50 \%$ & 4 \\
Bonus (break-adjusted) & $8.10 \%$ & 2 \\
Stock-Price & $0 \%$ & 3 \\
\end{tabular}

may well be due to a structural break in 1884 when the new laws were introduced. Hence, we estimate the direct impact of the reform on the rewards, specifying the rewards as an AR(1) with fixed bank effects and a trend. Moreover, we include a dummy for the post-reform effect. When we subtract the estimate of the reform-dummy from our original rewards-series, we can clearly reject the hypothesis of a unit-root at the $10 \%$ level. This result can also be interpreted as some first indicator of a structural break indeed taking place in 1884. Moreover, in our more structural estimations (below), the autoregressive parameter is significantly smaller than one.

\section{Empirical results}

Our empirical model directly builds upon the assumption of a linear contract.

Hence, we specify

$$
w_{i t}=\alpha_{0 i}+a_{1} \pi_{i t}+\alpha_{2} \pi_{i t} \mathbb{I}_{t \geq 1885}+\beta x_{i t}+\gamma z_{t}+u_{i t}
$$

in which $w_{i t}$ is the average bonus paid to the members of the board. $\pi_{i t}$ is the profit of firm i at time $\mathrm{t}, x_{i t}$ are other individual covariates and $z_{t}$ denotes a vector of aggregate covariates. $\mathbb{I}$ is an indicator function that takes value one for the years after the reform year 1884 . 
In our vector of covariates $x_{i t}$ we also include an interaction term for profits and the average time the members of the board have spent on the board. This term represents the experience of the board members. We can expect the parameter for this term to be positive for two reasons: Firstly, if the board members get more experienced and build up more firm-specific human capital, their influence on the banks profits gets larger. Secondly, more experienced managers can be expected to divert bank resources to private projects more easily. Hence, they have to be compensated by a larger fraction of the profits for not doing so.

Econometrically, two problems may complicate our analysis. The first one is that bonus payments are bounded by zero, so that a Tobit-model would be appropriate. However, there are not too many observations in the censored region, so that a Panel-Tobit and a random-effects model do not yield substantial differences (both not reported). The other problem is the dynamic structure of our data, which we have to take into account as the unit-root hypothesis is clearly rejected. ${ }^{11}$ If the error term is autocorrelated, i.e. $u_{i t}=\rho u_{i t-1}+\xi_{i t}+\rho \alpha_{0 i}$, the estimation equation becomes

$$
\begin{array}{r}
w_{i t}=\rho w_{i t-1}+\alpha_{0 i}+\left(a_{1}+\alpha_{2} \mathbb{I}_{t \geq 1885}\right) \pi_{i t}-\rho\left(a_{1}+\alpha_{2} \mathbb{I}_{t \geq 1885}\right) \pi_{i t-1} \\
+\beta x_{i t}-\beta \rho x_{i t-1}+\gamma z_{t}-\gamma \rho z_{t-1}+\xi_{i t}, \\
=\rho w_{i t-1}+\alpha_{0 i}+\left(a_{1}+\alpha_{2} \mathbb{I}_{t \geq 1885}\right) \pi_{i t}-\left(\theta_{1}+\theta_{2} \mathbb{I}_{t \geq 1885}\right) \pi_{i t-1} \\
+\beta x_{i t}-\theta_{3} x_{i t-1}+\gamma z_{t}-\theta_{4} z_{t-1}+\xi_{i t} .
\end{array}
$$

As the reform was intended to improve corporate governance structures, we expect $\alpha_{2}>0$. Moreover, we expect tenure to increase the pay-performance sensitivity.

We use the Arrellano and Bond (1991) GMM estimator, to estimate this equation in a first step. This estimator does not make use of the parameter constraints between $(\rho, \alpha, \theta, \gamma)$. The regression results are presented in Table 3 .

\footnotetext{
${ }^{11}$ Although it would be generally speaking possible to adress both the censored regression and the dynamics-problem at once, e.g. using CLAD, the sample size makes this approach infeasible.
} 
Table 3: Arrelano-Bond-Estimator

\begin{tabular}{|c|c|c|c|c|}
\hline \multirow[t]{2}{*}{ Bonus } & \multicolumn{2}{|c|}{$\begin{array}{l}\text { One-step estimator, } \\
\text { including stock-prices }\end{array}$} & \multicolumn{2}{|c|}{$\begin{array}{l}\text { One-step estimator, } \\
\text { including aggregate variables }\end{array}$} \\
\hline & coefficient & std. error & coefficient & std. error \\
\hline L.Bonus & $0.7096^{* * *}$ & 0.0355 & $0.6308^{* * *}$ & 0.0360 \\
\hline Profit & $0.0288^{* * *}$ & 0.0040 & $0.0303^{* * *}$ & 0.0045 \\
\hline L.Profit & $-0.0183^{* * *}$ & 0.0043 & -0.0026 & 0.0052 \\
\hline Reform & $-0.0128^{* * *}$ & 0.0038 & $-0.0100^{* * *}$ & 0.0038 \\
\hline L.Reform & $0.0085^{* *}$ & 0.0038 & $0.0075^{* *}$ & 0.0038 \\
\hline Experience & $0.0009^{* * *}$ & 0.0002 & $0.0011^{* * *}$ & 0.0002 \\
\hline L.Experience & $-0.0010^{* * *}$ & 0.0002 & $-0.0010^{* * *}$ & 0.0002 \\
\hline Dividend & & & -0.0083 & 0.0056 \\
\hline L.Dividend & & & $-0.0212^{* * *}$ & 0.0058 \\
\hline Stock-Price & 0.2197 & 0.2354 & & \\
\hline L.Stock-Price & $-0.5254^{*}$ & 0.2716 & & \\
\hline Trend & 1.1567 & 0.5855 & -1.7052 & 1.4198 \\
\hline NNP & & & -0.0008 & 0.0030 \\
\hline L.NNP & & & 0.0054 & 0.0029 \\
\hline Stock Market Index & 0.0664 & 0.2516 & -0.3373 & 0.3654 \\
\hline L. SMI & -0.3291 & 0.2337 & -0.3592 & 0.2504 \\
\hline Real interest rate (i) & & & -1.8149 & 1.6698 \\
\hline L.i & & & -1.2900 & 1.4378 \\
\hline Consistency Tests & statistics & P-Value & statistics & P-Value \\
\hline Sargan $\chi^{2}(741)$ & 376.13 & 1 & 359.09 & 1 \\
\hline Second order & & & & \\
\hline autocorrelation & 1.13 & 0.257 & 0.9 & 0.3656 \\
\hline
\end{tabular}

We included the stock-market index, NNP, and the real interest rate as controls for the aggregate state of the economy. Yet, none of them entered significantly. Moreover, we alternatively include dividends paid and the price of the bank's stocks in the set of regressors. ${ }^{12}$

The Sargan-test cannot reject the null of overidentification and so does the second-order autocorrelation-test not reject the null of no autocorrelation. So,

\footnotetext{
${ }^{12}$ We also tried other specifications, including the interaction of the share-price volatility and the profits (at annual frequencies, before and after the reform separately), we excluded the banks that appear in the sample only after the reform, treated experience as endogenous, and used the two-step procedure of Arrelano and Bond (1991). Another specification included total asset value as regressor and proxy for firm size. However, we excluded this variable from the final set of regressors as it exhibits a unit-root. Qualitatively, the results did not change across all different specifications.

Bonus payments were used instead of total compensation as only data on the bonus-part is available.
} 
Table 4: Baltagi-Wu Estimator

\begin{tabular}{l|lll}
\hline \hline \multirow{2}{*}{ Bonus } & \multicolumn{3}{l}{ Fixed Effects } \\
\cline { 2 - 3 } & coefficient & std. Err. & p-value \\
\hline Profit & 0.0284 & 0.0049 & 0.000 \\
Reform-Effect & -0.0140 & 0.0045 & 0.002 \\
Experience & 0.0004 & 0.0002 & 0.027 \\
Stock-Price & 1.0644 & 0.3067 & 0.001 \\
SMI & -0.1126 & 0.2680 & 0.675 \\
Constant & -108.90 & 7.71 & 0.000 \\
\hline \hline$\rho$ & 0.7827 & & P-Value \\
Hausmann-test & Statistics & 58.6 & 0
\end{tabular}

our model seems to be well specified.

The estimated parameters for the lagged independent variables are relatively close the values implied by the parameter-constraints from the AR(1)disturbance model. Hence, we also estimate (4) using the AR(1) panel estimator of Baltagi and Wu (1999). These estimates are reported in Table 4.

Here, a Hausmann-test clearly rejects the random effects model, so that we take the fixed-effects Baltagi-Wu estimates as our most preferred ones. Yet the Arrellano-Bond estimates do not qualitatively differ.

An increase in profits of $1000 \mathrm{M}$ increases the salary of the typical member of the board by $28.4 \mathrm{M}$ in the pre-reform period. ${ }^{13}$ However, the 1884-reform already halved the sensitivity. Insofar, we can clearly reject the hypothesis, that the contracts in the pre-reform period were not incentive related. Moreover, we find the tenure-effect to be also positive as predicted. Although the price of the bank's stocks enters the remuneration statistically significant, economicly it seems of lesser importance as the stock price's unit of measure is percent of the nominal value of equity.

\section{Conclusion}

In this paper, we have used a fundamental reform of the corporate governance code - the 1884 joint-stock company act in Germany — to test for incentive contracts. We find the pre-reform pay-performance sensitivity to be statistically

\footnotetext{
${ }^{13}$ Compared to the effect Jensen and Murphy (1990) found for modern US CEOcompensations, this is 8-times larger and may therefore be considered as substantial
} 
significant and economically important. As the reform about halved this sensitivity, we can attribute a substantial fraction of the sensitivity found to incentives. As for the post-reform period, naturally we can not exactly differentiate between general-equilibrium and incentive effects in the pay performance sensitivity. Yet, the large impact the reform itself has points towards a substantial incentive proportion in the sensitivity found, as the reform can be expected to not have wiped out all problems of corporate control but only a substantial fraction.

Our results may also be interpreted in another direction: Given the low payperformance sensitivity typically found in studies that use modern data, that is data from a well established system of corporate governance, inducing managers to exert effort seems not to be the major problem for the principal, but rather directing this effort to profitable activities is the main point of concern.

At least our results should make cautious when interpreting increases in the pay-performance sensitivity as improvements for the shareholders. Such increases might well reflect a worsening of institutions of corporate governance. 


\section{References}

Arellano, Manuel and Stephen Bond (1991): "Some Tests of Specification for Panel Data: Monte Carlo Evidence and an Application to Employment Equations", Review of Economic Studies, 58 (2), 277-97.

Aggraval, Rajesh K. and Andrew A. Samwick (1999): "The other Side of the Trade-off: The Impact of Risk on Executive Compensation" Journal of Political Economy, 107 (1), 65-105.

Bosenick, Alfred (1912): "Neudeutsche gemischte Bankwirtschaft - Ein Versuch zur Grundlegung des Bankwesens", "Volume 1", Schweizer Verlag, Munich.

Burhop, Carsten (2003): "Executive compensation and firm performance: The case of large German banks, 1853 -1910", Business History, forthcoming. (Paper presented at the 2003 Annual Conference of the Economic History Society)

Conyon, Martin J. (1997): "Corporate Governance and Executive Compensation", International Journal of Industrial Organizatrion, 15, 493-509.

Core, John E., Robert W. Holthausen, and David F. Larcker (1999):

"Corporate Governance, Chief Executive Officer Compensation, and Firm Performance", Journal of Financial Economics, 51, 371-406.

Core, John, Wayne R. Guay, and David F. Larcker (2003): "Executive Compensation and Incentives: A Survey", Federal Reserve Bank New York Policy Review April 2003, 27-50.

Garen, John E. (1994): "Executive Compensation and Principal Agent Theory", Journal of Political Economy, 102 (6), 1175-99.

Glagau, Otto (1877): "Der Börsen- und Gründungsschwindel in Deutschland", Verlag von Paul Frohberg, Leipzig.

Grossmann, Volker (2003): "Managerial Job Assignment and Imperfect Competition in Asymmetric Equilibrium", mimeo, University of Zurich.

Hall, Brian J. and Jeffrey B. Liebmann (1998) "Are CEOs really paid like bureaucrats?", Quarterly Journal of Economics, 113 (3), 653-91.

Himmelberg, Charles P. and Glenn Hubbard (2000): "Incentive Pay and the market for CEOs: An Analysis of Pay-for-Performance Sensitivity", Columbia Business School Working Paper.

Hoffmann, Walther G. (1965): "Das Wachstum der deutschen Wirtschaft seit der Mitte des 19. Jahrhunderts", Springer-Verlag, Berlin. 
Hopt, Klaus J. (1980): "Ideelle und wirtschaftliche Grundlagen der Aktien-, Bank- und Börsenrechtsentwicklung im 19. Jahrhundert", In: Coing, Helmut / Wilhelm, Walter (eds.), "Wissenschaft und Kodifikation des Privatrechts im 19. Jahrhundert", Bd. 5, "Geld und Banken", Fritz Knapp Verlag, Frankfurt a. M.

Jensen, Michael C. and Kevin J. Murphy (1990): "Performance Pay and TopManagement Incentives", Journal of Political Economy, 98 (2), 225-64.

John, Kose and Yiming Qian (2003): "Incentive Features in the Banking Industry", Federal Reserve Bank New York Policy Review April 2003, 109-121.

Kato, Takao (1997): "Chief Executive Compensation and Corporate Groups in Japan: New Evidence from Microdata", International Journal of Industrial Organization, 15, 455-67.

Kraft, Kornelius and Antonia Niederprüm (1999a): "Ist die Vergütung von Managern im Zeitablauf flexibler geworden?", Zeitschrift für betriebswirtschaftliche Forschung, 51, 1999, 787 - 804.

Kraft, Kornelius and Antonia Niederprüm (1999b): "Determinants of management compensation with risk-averse agents and dispersed ownership firm", Journal of Economic Behavior \& Organization, 1999, 17-27.

Lambert, Richard A. and David F. Larcker (1987): "An Analysis of the Use of Accounting and Market Measures of Performance in Executive Compensation Contracts", Journal of Accounting Research, 25 , 85-125.

Lazear, Edward P. (2003): "Output-Based Pay: Incentives, Retention or Sorting?", IZA DP. No. 761.

Maddala, G.S. and Shaowen Wu "A Comparative of Unit-Root Tests with Panel Data and a New Simple Test", Oxford Bulletin of Economics and Statistics, Special Issue, 61 (0), 631-52.

Murphy, Kevin J. (1999): "Executive Compensation", In Orley Ashenfelter and David Card (eds.): "Handbook of Labor Economics" Vol. 3B, NorthHolland, Amsterdam, 2485-2563.

Philippovich, Eugen von (1909): "Grundriß der politischen Ökonomie", Volume 2, Part 1, 4th Edition, J.C.B. Mohr, Tübingen.

Reitmayer, Morten (1999): "Bankiers im Kaiserreich", Vandenhoeck\&Ruprecht, Göttingen.

Ring, (1890): "Das Aktienrecht in Deutschland", In: Conrad, J. et al. (eds.), "Handwörterbuch der Staatswissenschaften", Vol. 1, 85 - 101, Verlag von Gustav Fischer, Jena.

Schwalbach, Joachim and Ulrike Graßhoff (1997): "Managervergütung und Unternehmenserfolg", Zeitschrift für Betriebswirtschaftslehre, 67, 1997, $203-217$. 
Shleifer, Andrei and Robert W. Vishny (1997): "A Survey of Corporate Governance", Journal of Finance, 52 (2), 737-783.

Warschauer, Otto (1902): "Die Reorganisation des Aufsichtsratswesens in Deutschland", Freier Verlag, Berlin.

Zhou, Xianming (2000): "CEO pay, firm size, and corporate performance: evidence from Canada", Canadian Journal of Economics, 33(1), 213-251. 


\title{
A Corporate Governance reform as a natural experiment for incentive contracts Appendix for the referee
}

\author{
Christian Bayer Carsten Burhop
}

June 25, 2003

\section{Optimal contract}

Taking our "model" from the main text, with the quadratic specification for the cost-function $g$, we obtain for the first-order condition of the manager:

$$
1-c(s-b \pi) \pi^{-1}=a \Longleftrightarrow s(a)=\pi\left(\frac{1-a}{c}+b\right) .
$$

For the owner's profit, we hence obtain

$$
\Pi(a)=\pi\left(1-\frac{1-a}{c}-b\right)(1-a)=\pi\left((1-b)(1-a)-\frac{(1-a)^{2}}{c}\right)
$$

And thus for the first-oder condition, which determines the optimal pay performance sensitivity:

$$
\begin{aligned}
\Pi^{\prime}(a) & =\pi\left(-(1-b)+\frac{2(1-a)}{c}\right) \stackrel{!}{=} 0 \\
& \Longleftrightarrow a=1-\frac{(1-b) c}{2}
\end{aligned}
$$

\section{Further Information on the data}

The banks included in the sample are: Schaaffhausenscher Bankverein, Bank für Handel und Industrie, Disconto-Gesellschaft, Berliner Handels-Gesellschaft, 
Mitteldeutsche Creditbank, Deutsche Bank, Commerz- und Discontobank, Dresdner Bank, Nationalbank für Deutschland.

Therefore in comparison with other recent studies our sample is small along the cross-sectional dimension. In a sense it is not random as it has a bias toward large banks. Another shortcoming are the missing information about the fixed or basic salaries of the executives. Furthermore, it is not possible to figure out how the bonuses were distributed within the board. See Burhop (2003) on these points. 